\title{
LCA APPLIED TO AN ANAEROBIC DIGESTION PLANT FOR BIOMETHANE AND DIGESTATE PRODUCTION
}

Carlo GRECO, Council for Agricultural Research and Economics (CREA), Research Centre Protection and Certification, S.S. 113 - Km 245.500, 90011 Bagheria, Italy, carlo.greco@unipa.it

Antonio COMPARETTI, Department of Agricultural, Food and Forest Sciences (SAAF), University of Palermo, Piazza Marina, 61, 90133 Palermo PA, Italy, antonio.comparetti@unipa.it

Pierluigi FEBO, Department of Agricultural, Food and Forest Sciences (SAAF), University of Palermo, Piazza Marina, 61, 90133 Palermo PA, Italy, pierluigi.febo@unipa.it

Kęstutis NAVICKAS, , Institute of Energy and Biotechnology Engineering, Vytautas Magnus University, Donelaičio g. 58, LT-44248 Kaunas, Lithuania, kestutis.navickas@vdu.lt

Santo ORLANDO, Department of Agricultural, Food and Forest Sciences (SAAF), University of Palermo, Piazza Marina, 61, 90133 Palermo PA, Italy, santo.orlando@unipa.it

Kęstutis VENSLAUSKAS, , Institute of Energy and Biotechnology Engineering, Vytautas Magnus University, Donelaičio g. 58, LT44248 Kaunas, Lithuania, kestutis.venclauskas@vdu.lt (corresponding author)

Nowadays it is paramount to promote bioenergy for climate protection, energy security and creation of income/jobs. In this perspective, Anaerobic Digestion (AD) for biogas and digestate production seems to be a viable way to simultaneously improve waste management while producing Renewable Energy Sources (RES). The main objective of this work is to assess the environmental impact associated with biomethane and digestate production from an AD plant as Global Warming Potential, expressed in $\mathrm{CO}_{2}$ equivalents. Therefore, a LCA was carried out for the production of biomethane ready for the injection into the Italian distribution natural gas grid.

A mix from different waste sources (cattle manure and slurry, pig slurry, Citrus industry by-product, chicken manure, manure from broilers, triticale silage and waste from vegetable cleaning) is considered for biogas and digestate production. Besides biomethane this plant will produce digestate, that is a biological and nutrient-rich fertiliser. Thus, the cycle of circular economy is closed, as the recovery of matter and energy is carried out from waste.

The results clearly indicate the importance of the process steps transport of biomass to $\mathrm{AD}$ plant and, above all, methane upgrading (separation by membrane). Depending on the high amount of the substrate and long distance travelled, Citrus waste substrate transport accounts for the largest share in GHG emissions with $0.229 \mathrm{~kg} \mathrm{CO}{ }_{2}$-eq $/ \mathrm{Nm}^{3}$ or $70.5 \%$ of total transportation emission. Greenhouse gas emissions estimated for the various process stages for the Sclafani Bagni plant showed, that methane upgrading emits $1.95 \mathrm{~kg} \mathrm{CO}_{2}$-eq/ $/ \mathrm{Nm}^{3}$, while other processes totally emits $0.525 \mathrm{~kg} \mathrm{CO}$-eq/ $/ \mathrm{Nm}^{3}$. The LCIA results confirmed the negative total impact of the process with grid injection, in terms of $\mathrm{kg}$ of $\mathrm{CO}_{2}$ eq.: the LCA verified the carbon-negative-bio-energy concept of the project. Therefore, biomethane derived from biogas is an entirely renewable and readily available low carbon alternative fuel, that can be locally produced from organic waste and capable to replace the fossil natural gas in the near future.

Keywords: Bioenergy, biogas, environmental impact, natural gas, Renewable Energy Sources (RES).

\section{INTRODUCTION}

The reduction of $20 \%$ in $\mathrm{CO}_{2}$ emissions, raising the share of European Union energy consumption produced from Renewable Energy Sources (RES) to $20 \%$ and a $20 \%$ improvement in the European energy efficiency are the three key goals of the European Commission energy policy for the year 2020.

In order to fulfil the above objectives, the European Commission encourages the use of alternative biofuels to replace diesel and petrol (EU, 2009). One of these biofuels is biogas, that is a clean and renewable bioenergy deriving from organic waste. Biogas is a mixture which mainly consists of methane $\left(\mathrm{CH}_{4}\right)$ but also carbon dioxide $\left(\mathrm{CO}_{2}\right)$ and several impurities. Biogas can be purified to increase its methane content, thus providing a promising energy carrier, i.e. biomethane. In fact, biomethane is obtained from biogas by means of a purification process called upgrading (Chandra et al., 2012). The upgrading technologies remove $\mathrm{CO}_{2}$ and other impurities from biogas, in order to increase the concentration of biomethane up to more than 95\%. Currently, the main upgrading technologies available, that can be differentiated according to their $\mathrm{CO}_{2}$ removal method, are: cryogenic or separation by membrane (considered in this study), adsorption (Pressure Swing Adsorption - PSA), absorption (chemical scrubbing with amine, High Pressure Water Scrubbing - HPWS). Generally, $\mathrm{CO}_{2}$ can be recovered and reused for other industrial applications (Comparetti et al., 2013a; Florio et al., 2019). Biomethane is a renewable energy similar to natural gas that can be used as a non-pollutant vehicle fuel and/or injected into the Italian distribution natural gas grid, similarly to fossil-based methane (Comparetti et al., 2015).

Copyright () 2019 The Authors. Published by Vytautas Magnus University. This is an open-access article distributed under the terms of the Creative Commons Attribution License (CC BY 4.0), which permits unrestricted use, distribution, and reproduction in any medium, provided the original author and source are credited. 
The pure $\mathrm{CO}_{2}$ can be used to enhance algae growth (Singh, Satendra \& Singh, Priyanka 2014), while the biomethane can be stored in a fuelling station. From this station a natural gas lorry can be refilled, as well as a portable injection system, in order to store and transport the renewable gas to a point where it can be injected into the Italian distribution natural gas network.

Nowadays it is paramount to promote bioenergy for climate protection, energy security (i.e. reduction of energy imports and dependencies from fossil energy carriers) and creation of income/jobs (direct, i.e. creation of income in rural areas, and indirect, i.e. development of an economy based on biomass/bioenergy).

EU Commission has introduced a number of sustainable criteria to be fulfilled, established by the Renewable Energy Directive (RED) 2009/28/EC.

The basic idea of the Life Cycle Assessment (LCA) methodology is the quantification of environmental impacts of a product system throughout its life cycle.

The Annex V of the EU Directive RED methodology clearly defines the basic framework of the investigation:

system boundaries (well-to-wheel);

- allocation of by-products, based on the Lower Heating Value (LHV) of products and by-products;

- functional unit for the expression of the result calculated (e.g. $1 \mathrm{~m}^{3}$ of biomethane at $\mathrm{STP}-0^{\circ} \mathrm{C}$ and $100 \mathrm{kPa}$ );

- $\quad$ Life Cycle Impact Assessment (LCIA) approach, i.e. GHG (Greenhouse Gas) emissions;

- characterisation factors for the conversion of GHG into $\mathrm{CO}_{2}$-equivalents;

- reference value for the comparison and interpretation of the results.

The conventional storage of manure leads to GHG emissions and can be a significant contributor to these emissions from agricultural sector. Instead the use of manure for biogas production can avoid emissions.

As far as the allocation of the digestate from biogas/biomethane production:

- the EU RED methodology allows only one allocation approach (based on the LHV); this does not necessarily reflect the true value of the digestate, that is often used as fertiliser and, thus, substitutes synthetic chemical fertiliser in agricultural production processes;

- separating the digestate into a dry and a liquid phase, in order to reduce its water content, can help to allocate a bigger part of the overall emissions to the digestate and, thus, increase the GHG-mitigation potential of the biomethane.

The GHG-emission savings from the Anaerobic Digestion (AD) of agricultural by-products and organic residues and wastes (e.g. manure) and, thus, the avoidance of emissions from the conventional treatment of these materials can have a significant impact on the overall result of the GHG-mitigation potential for biomethane (Comparetti et al., 2013a).

In recent years, a growing interest has arisen in the generation and use of Renewable Energy Sources (RES), to switch from fossil-based to more sustainable production and consumption patterns. Bioenergy from waste feedstock represents a valuable prospect that increasingly attracts the attention of populations and governments towards waste-based biorefinery processes. In this perspective, $\mathrm{AD}$ for biogas and digestate production seems to be a viable way to simultaneously improve waste management while producing RES.

In Europe, biomass currently accounts for $2 / 3$ of RES and will play a key role in achieving the target approved by the renewable energy Directive of $20 \%$ of final energy consumption based on RES by 2020 (AEBIOM, 2009). In Germany, biomass accounted for 8.2\% ca. of the primary energy demand in 2013 (FNR, 2014). Examples of biofuels produced from biomass include bioethanol, biodiesel and biogas. Currently, Germany is the world leader in the deployment of biogas technology and plays the leading role in the European biogas market (Sorda et al., 2013). The number of biogas plants in Germany increased from 1050 in 2000 to 7850 in 2013. With respect to overall biogas production, Germany is followed by United Kingdom, France, Italy and Netherlands (Van Foreest, 2012). Biogas is used in Combined Heat and Power (CHP) units to produce electricity and heat. In 2013, primary production of biogas in Europe (including landfills and sewage gas) was estimated as 13.4 Mtoe, i.e. million tons of oil equivalents (EurObserv'ER, 2015).

In Italy, new legislation concerning biomethane has recently been approved, by promoting its use in the transport sector with the aim of diversifying and decarbonising natural gas. In addition, financial incentives have also been established for new biogas plants that will be converted to biomethane production (Comparetti et al., 2012, 2013b; Florio et al., 2019).

The main objective of this work is to assess the environmental impact associated with biomethane and digestate production and the injection of biomethane itself into the Italian distribution natural gas network from a biogas production plant. Therefore, a LCA was carried out for the production of biomethane ready for the injection into the natural gas grid.

\section{METHODS}

LCA is a methodology for the comprehensive assessment of the environmental impact associated to a product or process during its life cycle (from extraction of raw materials to product disposal at the end of use) and it is sometimes referred to as cradle-to-grave analysis. However, when the system boundaries are restricted to selected life cycle stages (e.g. from raw materials extraction to product manufacture, as in the investigated case study), a cradle-to-gate perspective can be applied.

According to the ISO standards, this LCA consists of four interrelated components: (i) goal and scope definition; (ii) inventory analysis; (iii) impact assessment and (iv) interpretation of results for explanation of conclusions and recommendations.

The goals of this study are: 
- to measure the environmental impact of an $\mathrm{AD}$ plant for biomethane and digestate production;

- to identify the environmental hotspots in the production cycle carried out in an AD plant for obtaining biomethane and digestate.

The Functional Unit (F.U.) selected is $1 \mathrm{~m}^{3}$ of biomethane (at STP $-0^{\circ} \mathrm{C}$ and $100 \mathrm{kPa}$ ) produced from biogenic waste feedstock, after upgrading process (separation by membrane) but before injection to natural gas grid or transport: it represents the reference to which all the inputs and outputs of the system are adjusted. The boundary of the investigated system is defined from cradle to gate, being limited to the biogas production and conversion into biomethane and digestate, while neglecting any following use. Data for a mix from different waste sources (cattle manure and slurry, pig slurry, Citrus industry byproduct, chicken manure, manure from broilers, triticale silage and waste from vegetable cleaning) is considered for biogas and digestate production by means of $\mathrm{AD}$ and were taken from Ecoinvent database v.3.4 (Wernet et al., 2016). The Life Cycle Impact Assessment (LCIA) of the F.U. is carried out by using the SimaPro software, version 8.0. In particular, the impact assessment is performed by means of one of the most recent and up-to-date LCA methods, the CML-IA baseline V 3.00. In this study, according to the recommendations from the ILCD Handbook, the Global Warming (GWP100a) midpoint impact category is analysed. The data about the means of transport used for transferring the substrates to the biogas plant were drawn from a previous paper (Comparetti et al., 2014). The methodology used for LCA is defined in the ISO Standard 14040:2006 and ISO Standard 14044:2006. Greenhouse gas emissions are expressed as GWP100 in accordance with IPCC (International Panel for Climate Change) guidelines and describe the contribution of emissions to the greenhouse effect over 100 years and thus also climate change. In the case of biofuels, " $\mathrm{CO}_{2}$ equivalents" refers to all the emissions of the GHG carbon dioxide $\left(\mathrm{CO}_{2}\right)$, methane $\left(\mathrm{CH}_{4}\right)$ and nitrous oxide $\left(\mathrm{N}_{2} \mathrm{O}\right)$, which are converted by using appropriate IPCC 2007 factors.

The process has been divided into three systems:

1. pre-treatment of the raw materials;

2. anaerobic digestion of the raw materials;

3. biogas upgrading.

In order to transform Fontana Murata farm into a multifunctional agriculture one, an AD plant will be built up, together with the structures for the storage and treatment of raw materials and products. It will transform the following organic agricultural and food raw materials, available within the following distances from the plant itself, into biogas and digestate:

- cattle manure $(10 \mathrm{~km})$

- $\quad$ cattle slurry $(10 \mathrm{~km})$;

- pig slurry $(40 \mathrm{~km})$;

- $\quad$ Citrus industry by-product $(150 \mathrm{~km})($ Comparetti et al., 2017);

- $\quad$ chicken manure $(100 \mathrm{~km})$;

- manure from broilers $(100 \mathrm{~km})$;

- $\quad$ triticale silage $(3 \mathrm{~km})$;

- $\quad$ waste from vegetable cleaning $(3 \mathrm{~km})$.

The biogas will be upgraded to biomethane, that is a renewable biofuel chemically equal to fossil methane but having pollutant emissions highly lower than alternative fuels. Besides biomethane this plant will produce digestate, that is a biological and nutrient-rich fertiliser. Thus, the cycle of circular economy is closed, as the recovery of matter and energy is carried out from waste. The experience basis for this study is a modern biomethane plant to be built up in Sclafani Bagni (Palermo)/Italy, which will be operated by Fontana Murata farm. The plant will be run with a mix of the above raw materials. Among the upgrading technologies, the separation by membrane was selected, because it generates the lowest impacts on all the investigated categories (Florio et al., 2019).

The basic processes and system limits of the biomethane production plant in Sclafani Bagni are specified in Figure 1.

\section{RESEARCH RESULTS}

The main examined process steps are: transport of biomass to AD plant; digestate spreading; biogas production; methane upgrading.

The GHG emissions estimated for the various process stages are shown for the Sclafani Bagni plant in Figure 2. The results clearly indicate the importance of the process steps transport of biomass to AD plant and, above all, methane upgrading. In the transport of biomass to AD plant, GHG emissions are significantly lower compared to the emissions from methane upgrading. In order to sustain a long-term operation of the $\mathrm{AD}$ plant, quantities of feedstock are stored depending on the plant size. In addition, the covered storage of substrates serves as a biochemical preservation (Soukup, 2008).

From the preloading tank (only for cattle and pig slurry) or trench (for all the other substrates), the substrates enter six digesters, where the $\mathrm{AD}$ process is carried out for biogas and digestate production. 


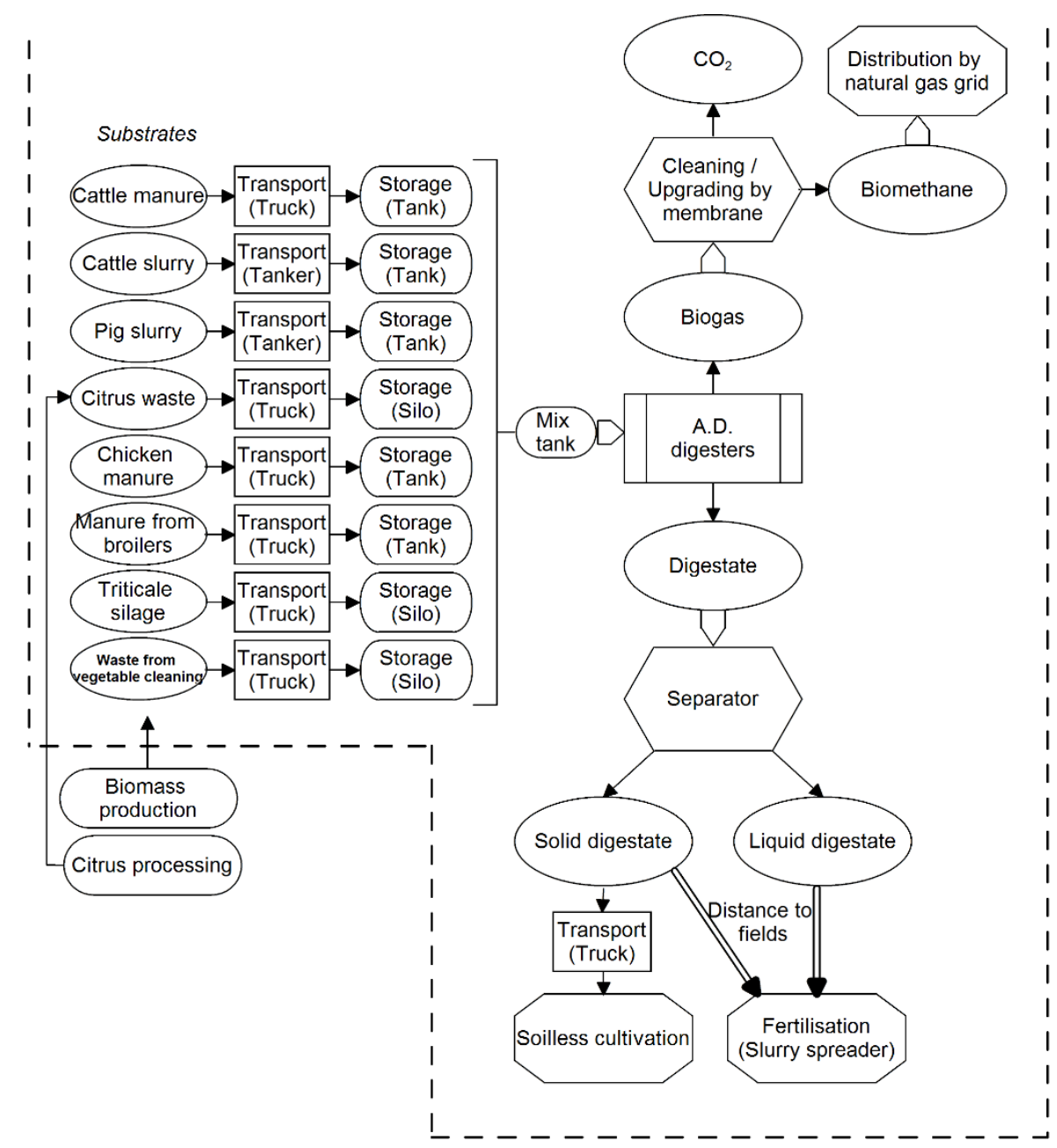

Figure 1. Basic processes and system limits of the biomethane production plant in Sclafani Bagni.

GHG calculations for biomethane production processes usually identify the supply of process energy (both electricity and heat), as well as the direct methane emissions as relevant parameters. For the operation of the biogas digesters, thermal (e.g. for setting up the ideal temperature conditions) and electrical energy are required. Depending on the actual configuration of the plant, both demands can be meet by using internal solutions for energy provision (i.e. CHP unit). Since the GHG methane has a much higher climate efficiency than, for example, $\mathrm{CO}_{2}$, the magnitude of these emissions can decisively influence the overall result. In digester operation, leakages and disturbances can lead to methane leaks. Such leakages are caused by a multiplicity of influencing factors: the available scientific literature sources typically indicate diffuse methane emissions of $1 \% \mathrm{ca}$. for the process of biogas production (Bachmaier et al., 2007; Müller-Langer et al., 2009). Significant differences can occur between the different processes of biogas upgrading. GHG emissions are associated with the whole production chain, i.e. substrate transportation, digestate spreading, biogas production, upgrading of biogas to biomethane. In this study the evaluation of the specified biomethane plant was verified on the basis of comprehensive measurements and experience data showing significant improvements. Greenhouse gas emissions estimated for the various process stages for the Sclafani Bagni plant showed, that methane upgrading emits $1.95 \mathrm{~kg} \mathrm{CO}$-eq $/ \mathrm{Nm}^{3}$, while other processes totally emits $0.525 \mathrm{~kg} \mathrm{CO}$-eq $/ \mathrm{Nm}^{3}$. Transportation process (including all types of feedstock) accounts for $0.325 \mathrm{~kg} \mathrm{CO}$-eq/ $\mathrm{Nm}^{3}$.

As expected, depending on the high amount of the substrate and long distance transported $(150 \mathrm{~km})$, Citrus waste substrate transport accounts for the largest share in GHG emissions (Fig 3) reaching emissions of $0.229 \mathrm{~kg} \mathrm{CO}$-eq $/ \mathrm{Nm}^{3}$ or $70.5 \%$ of total transportation emission. Instead cattle manure and slurry, triticale silage and waste from vegetable cleaning account for negligible shares in GHG emissions. Thus, designing waste treatment technologies, the distance and energy value of feedstock must be taken into consideration, otherwise the sustainable system could become harmful. 


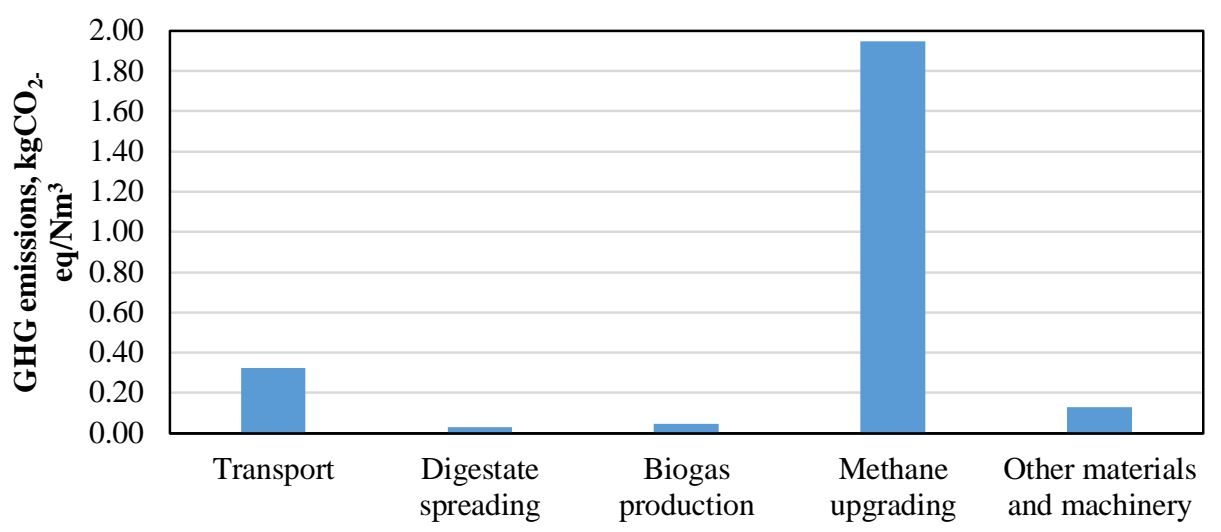

Figure 2. Greenhouse gas (GHG) emissions estimated for the various process stages for the Sclafani Bagni plant.

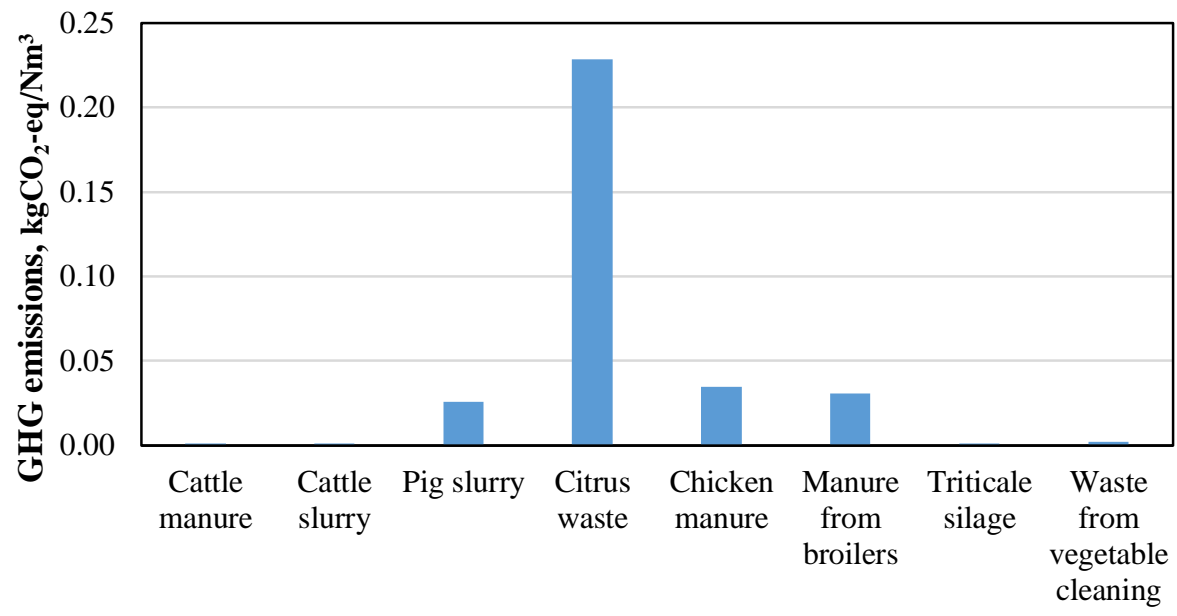

Figure 3. Greenhouse gas (GHG) emissions estimated for the various feedstock transportation processes.

A direct comparison of the results achieved in this study with previous LCA literature is challenging, due to differences in the selection of F.U., system boundaries, impact assessment methods and the modelled sources of avoided burdens and in the process yields, which vary according to local conditions and technologies levels. However, the results achieved by Florio et al. (2019), whose study was aimed at assessing the environmental costs and benefits of different uses of biogas, by comparing upgrading technologies for biomethane production with the conventional on-site cogeneration, show a better environmental performance of the cogeneration option in most of the impact categories and highlight the benefits that can be gained in each impact category by means of substitution of natural gas with biomethane. At the same time, these results, based on the $1 \mathrm{~m}^{3}$ of biogas as F.U., show a significant share of environmental impact generated by the fate of digestate produced as $\mathrm{AD}$ co-product: substantial savings in terms of environmental impact can be obtained by using the digestate as fertiliser, thus avoiding the impact of fossil-based synthetic fertilisers. This result confirms that substrate choice is important in the management of biogas life cycle impacts. Poeschl et al. (2012), for instance, calculated that biogas from straw feedstock could achieve up to a ten times higher impact reduction in Global Warming Potential compared to cattle manure. Therefore, the composition of the mix of waste sources for $\mathrm{AD}$ may determine significant variations in all environmental impact categories.

\section{CONCLUSIONS AND DISCUSSION}

The following measures are needed in order to minimise the environmental impact of Anaerobic Digestion plants:

- installing a flare to avoid discharge of biogas to the atmosphere during outages of the combined CHP unit and reducing methane leakage;

- covering the storage tank for digestate and collecting the residual biogas production;

- minimising the electricity demand of the biogas plant and supplying it from low-emission sources;

- using as much heat output from the CHP unit as possible to substitute fossil energy carriers;

- employing high-efficiency CHP units, possibly with additional exhaust gas treatment;

- checking the AD plant for leakages on a regular basis (Hijazi et al., 2016). 
Natural gas is classified as fossil fuel, whereas biomethane is defined as a green source of energy. Like its name suggests, fossil fuel derived methane is produced from thousands or millions of years. Production of fossil fuel derived methane, however, depends exclusively on its natural reserves, which highly vary from one country to another and are available in limited amounts. The biomethane, conversely, is produced from organic matter, which makes it a renewable source of energy that can be produced worldwide.

The use of biomethane or renewable natural gas has a great potential with important socio-economic benefits. Moreover, taking into account the environmental assessment, the main conclusions are the following:

- the stage with a major environmental significance throughout the life cycle of the product under study is methane upgrading with GHG emissions of about $2 \mathrm{~kg} \mathrm{CO}$-eq/ $/ \mathrm{Nm}^{3}$, while the stage with the lowest environmental impact is digestate spreading with about $0 \mathrm{~kg} \mathrm{CO}$-eq/ $/ \mathrm{Nm}^{3}$;

- taking into account the $\mathrm{CO}_{2}$ capture from manure, the negative total impact of biogas production and upgrading processes means that the manure has captured more $\mathrm{CO}_{2}$ than all the process consumptions together, e.g. electricity, water and chemical products;

- the results for the LCA of the system confirmed the negative total impact of the process with grid injection, in terms of $\mathrm{kg}$ of $\mathrm{CO}_{2}$ eq.: the LCA verified the carbon-negative-bio-energy concept of the project.

Therefore, biomethane derived from biogas is an entirely renewable and readily available low carbon alternative fuel, that can be locally produced from organic waste and capable to replace the fossil natural gas in the near future.

Biomethane is currently the most important renewable option for gas supplies and is fully compatible with natural gas. The most effective measure which can be implemented in order to reduce GHG emissions in substrate production is to use the digestate as a fertiliser, allowing the replacement of $100 \%$ of $\mathrm{K}$ and $\mathrm{P}$ fertilisers, as well as $60 \%$ of the $\mathrm{N}$ fertiliser, which is associated with the highest GHG emissions.

\section{REFERENCES}

1. AEBIOM, European Biomass Association, 2009. A Biogas Road Map for Europe, Renewable Energy House, Belgium.

2. Bachmaier J., Gronauer A., 2007. Klimabilanz von Biogasstrom - Klimabilanz der energetischen Nutzung von Biogas aus Wirtschaftsdüngern und nachwach-senden Rohstoffen. Bayrische Landesanstalt für Landwirtschaft, Freisingen.

3. Chandra R. .V., Subbarao P. M. V. 2012. Vehicular Quality Biomethane Production from Biogas by Using an Automated Water Scrubbing System. International Scholarly Research Network ISRN Renewable Energy, Vol. 2012, Article ID 904167,6 p. https://doi.org/10.5402/2012/904167

4. Comparetti A., Greco C., Navickas K., Venslauskas K. 2012. Evaluation of potential biogas production in Sicily. Proceedings of the $11^{\text {th }}$ International Scientific Conference Engineering for Rural Development, Jelgava, Latvia, 24-25, pp. 555-559.

5. Comparetti A., Febo P., Greco C., Orlando O. 2013a. Current state and future of biogas and digestate production. Bulgarian Journal of Agricultural Science, Vol. 19 (1), pp. 1-14.

6. Comparetti A., Febo P., Greco C., Navickas K., Nekrosius A., Orlando S., Venslauskas K. 2013b. Sicilian potential biogas production. X Convegno Nazionale di Ingegneria Agraria, Viterbo, Journal of Agricultural Engineering, Vol. XLIV(s2):e103, pp. 522-525.

7. Comparetti A., Febo P., Greco C., Navickas K., Nekrosius A., Orlando S., Venslauskas K. 2014. Assessment of organic waste management methods through energy balance. American Journal of Applied Sciences, Vol. 11(9), pp. 1631-1644. https://doi.org/10.3844/ajassp.2014.1631.1644

8. Comparetti A., Febo P., Greco C., Orlando S. 2015. Italian Potential Biogas and Biomethane Production from OFMSW. IV International Conference Ragusa SHWA on "Safety, Health and Welfare in Agriculture, Agro-food and Forestry Systems", Lodi, Italy, 8-11 September 2015, pp. pp. 206-215.

9. Comparetti A., Febo P., Greco C., Mammano M.M., Orlando S. 2017. Sicilian potential biogas production from Citrus industry by-product. Proceedings of 11th International AIIA (Italian Association of Agricultural Engineering), July 5-8, 2016 Bari, Italy, pp. $169-173$.

10. EU, Directive 2009/28/EC of the European Parliament and of the Council of 23 April 2009 on the promotion of the use of energy from renewable sources and amending and subsequently repealing Directives 2001/77/EC and 2003/30/EC.

11. EurObserv'ER, 2015. Biogas Barometer, $6 \mathrm{pp}$. available at web-site http://www.energiesrenouvelables.org/observer/stat_baro/observ/baro224_Biogas_en.pdf(verified July 22, 2015).

12. Florio C., Fiorentino G., Corcelli F., Ulgiati S., Dumontet S., Güsewell J., Eltrop L., 2019. A Life Cycle Assessment of Biomethane Production from Waste Feedstock Through Different Upgrading Technologies, Energies, MDPI, Basel, Switzerland. https://doi.org/10.3390/en12040718

13. FNR, 2014. Agency of Renewable Resources e. V. Basic data bioenergy Germany Deutschland 2013, available at web-site http://mediathek.fnr.de/media/downloadable/files/samples/b/a/basisdaten_9x16_2013_web_neu2.pdf (verified May 22, 2014).

14. Hijazi O., Munro S., Zerhusen B., Effenberger M., 2016. Review of life cycle assessment for biogas production in Europe. Renewable and Sustainable Energy Reviews, Vol. 54, pp. 1291-1300. https://doi.org/10.1016/j.rser.2015.10.013

15. Müller-Langer F., Rönsch S., Weithäuser M., Oehmichen K., Scholwin F., Höra S., Scheftelowitz M., Seiffert M., 2009. Ökonomische und ökologische Bewertung von Erdgassubstituten aus nachwachsenden Rohstoffen. Deutsches Biomasse Forschungszentrum gGmbH, Leipzig. 
16. Poeschl M., Ward S., Owende P., 2012. Environmental impacts of biogas deployment - Part II: Life cycle assessment of multiple production and utilization pathways. Journal of Cleaner Production, Vol. 24, pp. 184-201. https://doi.org/10.1016/i.jclepro.2011.10.030

17. Singh S.H., Singh P. 2014. Effect of CO2 concentration on algal growth: A review. Renewable and Sustainable Energy Reviews, Vol. 38, pp. 172-179. https://doi.org/10.1016/j.rser.2014.05.043

18. Sorda G., Sunak Y., Madlener,R., 2013. An agent-based spatial simulation to evaluate the promotion of electricity from agricultural biogas plants in Germany. Ecological Economics, Vol. 89, pp. 43-60. https://doi.org/10.1016/j.ecolecon.2013.01.022

19. Soukup O., 2008. Erstellung von Produktökobilanzen auf Basis von Stroffstrom-netzen für die Bereitstellung von Biogas zur Einspeisung in das Erdgasnetz. Wuppertal Institut.

20. Van Foreest F., 2012. Perspectives for Biogas in Europe, Oxford Institute for Energy Studies, NG 70, ISBN 978-1-907555-63-3.

21. Wernet G, Bauer C., Steubing B., Reinhard J., Moreno-Ruiz E., Weidema B. 2016. The ecoinvent database version 3 (part I): overview and methodology. The International Journal of Life Cycle Assessment, Vol. 21, pp. 1218-1230. https://doi.org/10.1007/s11367-016$\underline{1087-8}$ 